\title{
Use of Borogypsum as Secondary Raw
}

\author{
A. Khatkova ${ }^{1}$, L. Nikitina ${ }^{2}$, and S. Pateyuk ${ }^{2(\mathbb{} \times)}$ \\ ${ }^{1}$ Department of Mineral Technology, School of Geology, \\ Transbaikal State University, Chita, Russia \\ 2 Department of Geology, University of Kazan, Kazan, Russia \\ nesvvik@gmail.com
}

\begin{abstract}
We have considered problem of accumulation, storage, utilization and recycling of wastes of various industries. We chose borogypsum as the object of study, which contains gypsum and silicon dioxide, which can be used in various industries. We proposed a new flotation reagent for separation of silicon concentrate from wastes of boric acid production. Using methods of mathematical planning we conducted a multifactorial experiment, which allowed identifying optimal flotation mode. We developed a technology for processing of borogypsum.
\end{abstract}

Keywords: Secondary raw $\cdot$ Borogypsum $\cdot$ Flotation $\cdot$ Perlastane $\cdot$

White soot $\cdot$ Silicon concentrate

\section{Introduction}

Over the years the enterprises of mining and chemical industries in the Far East accumulated millions tons of industrial wastes that are currently not being recycled. Thus, the total amount of wastes from the production of boric acid - borogypsum - in the Far Eastern region is more than 25 million tons. Borogypsum contains gypsum and silicon dioxide, which can be used in various industries. In this regard, the problem of complex processing of these wastes to obtain various functional materials is a very urgent task (Gordienko et al. 2014).

Highly dispersed amorphous silica is referred to as white soot. White soot of all kinds, alongside with black ones, is used to strengthen rubber, being absolutely indispensable for silicone rubbers. It is also used as fillers in the production of rubber linoleum, as well as in plastics, paints, lubricants and other materials to give them valuable properties.

In addition to silicon dioxide, another component of borogypsum, gypsum and anhydrite, can be used in industry. All possible products (component for cement production, dry building mixtures, finished building and architectural products, gypsum boards) have positive market prospects in Russian markets and in some neighboring foreign markets.

In Russia there are projects for the production of white soot with a high silica content by separating from datolite tailings. However, such technologies are not implemented at industrial scale, because they are quite expensive due to the low content of silicon dioxide in the original product. 
To reduce the consumption of acids and the cost of production of white soot, it is necessary to increase the content of silicon dioxide in the original product by other cheaper methods such as flotation.

The table below shows the dependence of the need for concentrate on the content of silicon dioxide (Table 1).

Table 1. The dependence of the need for concentrate on the content of $\mathrm{SiO} 2$

\begin{tabular}{l|l|l|l}
\hline $\begin{array}{l}\mathrm{SiO}_{2} \text { content } \\
\text { in concentrate }\end{array}$ & $\begin{array}{l}\text { Need for } \\
\text { concentrate, } \\
\text { t/hour }\end{array}$ & $\begin{array}{l}\text { Need for sludge t/hour, with } \\
\text { a concentrate yield } 15 \%\end{array}$ & $\begin{array}{l}\text { Need for pulp volume, } \\
\mathrm{m}^{3} / \mathrm{h}, \text { at 20\% solids }\end{array}$ \\
\hline 65 & 1,35 & 9 & 40,1 \\
\hline 60 & 1,47 & 9,8 & 43,7 \\
\hline 55 & 1,60 & 10,7 & 47,7 \\
\hline 50 & 1,76 & 11,7 & 52,1 \\
\hline
\end{tabular}

According to the table, it is necessary to ensure the content of silicon dioxide from 50 to $65 \%$ with a product yield $15 \%$ and above using flotation.

\section{Methods and Approaches}

A sample of waste of boric acid production, borogypsum, obtained from Dalnegorsky MPP was selected as the object of study.

For the flotation of gypsum-containing raw, fatty acid reagents are commonly used (Bulut et al. 2008; Matsuno et al. 1958). We proposed a new flotation reagent perlastan ON 60 to isolate the silicon concentrate by reverse flotation. It was efficiently used at the flotation of non-metallic fluorite ores (Dolgikh 2012), and is a promising flotation reagent for borogypsum.

To determine optimal conditions for flotation, we used the method of rational planning of a multifactorial experiment (Malyshev 1977).

\section{Results and Discussion}

After conducting a multifactorial experiment, the following regularities were identified.

Increasing temperature of flotation leads to decreasing extraction, but at the same time, the content of silicon dioxide increases. It was also found that the temperature affects the floatability of gypsum, however, almost no effect on the floatability of silicon concentrate. Consequently, by changing the temperature, it is possible to regulate the process, depending on the task. Changes in flotation $\mathrm{pH}$ slightly affect the content and recovery, therefore, $\mathrm{pH}$ control is not effective, which in turn is an advantage of this method, for it does not require consumption of additional reagents. Increasing concentration of perlastane increases the content of silicon concentrate in the chamber product, however, the extraction drops significantly. The agitation time has a 
linear effect on the extraction, at the same time we didn't observe a clear dependence of the agitation time on the content. Therefore it is necessary to agitate perlastane with minerals for at least $3 \mathrm{~min}$. As the flotation time increases, the content slightly decreases due to the fact that alongside with calcium sulphate, silica dioxide begins to shift to the foam product.

On the basis of the revealed regularities we determined optimal conditions of flotation. However, the content of silicon concentrate in the chamber product remains insufficient.

From the literature it was found that sodium sulfide or liquid glass was often used to suppress flotation of quartz. Experiments with these reagents showed that they practically did not suppress flotation of amorphous silicon dioxide, and could also suppress flotation of gypsum, therefore it would be not advisable to use them for borogypsum flotation.

We determined that it would be much more effective to increase the concentration of perlastane at the main flotation, increasing its time than to feed the reagent fractionally in different operations. Increasing the concentration of perlastane up to $1 \mathrm{~kg} / \mathrm{t}$, as well as flotation time up to 9 min, allows obtaining a product with a content of $53.6 \%$, with a yield $32.5 \%$ and a recovery $64 \%$.

\section{Conclusions}

We suggested a new technology for processing wastes of boric acid production according to the scheme presented in Fig. 1. The proposed scheme has its advantages in comparison to previously known technologies. Thus it does not require regulation of $\mathrm{pH}$ of the medium, consists of a single operation, which significantly reduces flotation time and also allows to increase the yield of the chamber product significantly.

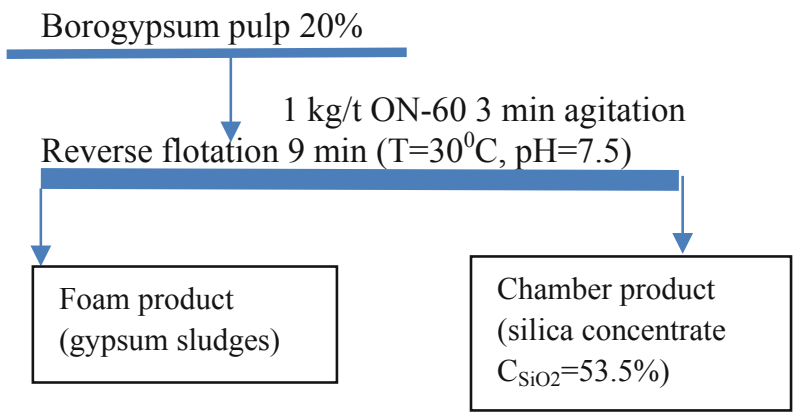

Fig. 1. Diagram of borogypsum flotation 


\section{References}

Bulut G, Atak S, Tuncer E (2008) Celestite-gypsum separation by flotation. Can J Metall Mater Sci 47(2):119-126

Dolgikh OL (2012) The use of perlastane reagent as an alternative to oleic acid during fluorite flotation. Bull ZabGU 9(88):20-26

Gordienko PS, Kozin AV, Yarusova, SB, Zgibly IG (2014) Integrated processing of waste from the production of boric acid to produce materials for the construction industry. Min Inf Anal Bull (S4-9):60-66

Malyshev VP (1977) Mathematical planning of metallurgical and chemical experiments. AlmaAta: Sci 35

Matsuno T, Kadota M, Ishiguro Y (1958) Separation of gypsum by the flotation process. Bull Soc Salt Sci 12(2):73-78

Open Access This chapter is licensed under the terms of the Creative Commons Attribution 4.0 International License (http://creativecommons.org/licenses/by/4.0/), which permits use, sharing, adaptation, distribution and reproduction in any medium or format, as long as you give appropriate credit to the original author(s) and the source, provide a link to the Creative Commons license and indicate if changes were made.

The images or other third party material in this chapter are included in the chapter's Creative Commons license, unless indicated otherwise in a credit line to the material. If material is not included in the chapter's Creative Commons license and your intended use is not permitted by statutory regulation or exceeds the permitted use, you will need to obtain permission directly from the copyright holder.

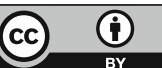

